\title{
Using Remote Sensing to Improve Crop Water Allocation in a Scarce Water Resources Environment
}

\author{
Fadi Karam ${ }^{1}$, Nabil Amacha ${ }^{1,2 *}$, Wassim Katerji ${ }^{3}$, Weicheng Wu ${ }^{4}$, Alfonso Domínguez ${ }^{5}$, Safa Baydoun ${ }^{6}$ \\ ${ }^{1}$ Litani River Basin Management Support (LRBMS) Program, Litani River Authority, Ghannajeh Bldg., $5^{\text {th }}$ floor, Bechara El Khoury \\ Street, P.O. Box: 11-3732,Beirut, Lebanon \\ ${ }^{2}$ Department of Biology, Faculty of Sciences I, The Lebanese University, Beirut, Lebanon
}

${ }^{3}$ Universidad Politécnica de Madrid, Spain

${ }^{4}$ State Key Laboratory \& Breeding Base of Nuclear Resources and Environment, East China Institute of Technology, Nanchang, Jiangxi 330013, China

${ }^{5}$ Centro Regional de Estudiosdel Agua (CREA), Universidad de Castilla-La Mancha, Ctra. de las Peňas, km 3.2, 02071 Albacete, Spain

${ }^{6}$ Research Center for Environment and Development, Beirut Arab University, Bekaa, Lebanon

\begin{abstract}
To understand the cropped areas and assess seasonal water supply for irrigation, remote sensing-based crop classification was conducted on satellite imagery data for a pilot area in the Bekaa Valley, Lebanon, during the 2011-2012 growing years. The crop classification was achieved using three sets of RapidEye and Landsat7 ETM+ (Enhanced Thematic Mapper Plus) images acquired in early (May), mid (July) and late (September) of 2011 and 2012 growing years, respectively. Field crop data were obtained throughout the growing seasons in well-defined farmers' plots before the images acquisitions using a hand-held GPS (Global Positioning System) Unit. Ten crop classification profiles and three non-crop profiles were derived for each year from the different class signatures in the preselected bands of the two satellite data. Then, image-derived results were checked for accuracy and used to produce cropping maps within GIS (Geographic Information System).These maps enabled us to define different cropping calendars and determine seasonal irrigation water requirements (IWRs) at the pilot area level. IWRs were calculated for the surveyed crops as the product of the produced cropping maps and net irrigation requirements (NIR)calculated by means of MOPECO(Economic Optimization Model for Irrigation Water Management). The results were compared with the Litani River Authority Database (LRAD) and found a good agreement. The classification results of RapidEye images (2011) compared quite well in the whole test area with Landsat derived crop maps (2012). The overall accuracy of the classification against the field data ranges from $84 \%$ to $95 \%$. In addition, crop classification profiles appeared consistent with field crop observations, even though a slight variation was noted. The examination of the crop maps showed decreases of as much as 7\%, 30\% and 5\%inbareland, woodland and fallow areas, respectively, in 2012 when compared to 2011. Data showed that these decreases were reported as increases in wheat (15\%), fruit trees (11\%), olive (6\%), and vineyard (3\%). The increased cropland that was observed in 2012 was accompanied by an increase in the amount of water allocated from the Canal 900 irrigation conveyor in comparison with that of 2011. This study presented an example of remote sensing application for water allocation in agriculture. It was concluded that satellite imagery was essential for the definition of the existing cropping patterns in the pilot area and helped better estimate seasonal irrigation needs at the scheme level. The proposed methodology may help irrigation deciders to better assess water resources with respect to the surveyed cropped areas.
\end{abstract}

Keywords: Satellite Imagery, Remote Sensing, Crop Signature, Cropping Pattern, Irrigation Water Requirements, Water Allocation

\section{Introduction}

The unavailability of reliable hydrological information about the actual water used by crops within irrigation schemes or at the whole basin level is a major constraint for sustainable management of water resources. Therefore, an estimation of the spatially distributed crop areas is important to determine crop water requirements and account for water balance at different scales of the irrigation scheme. This would promote efficient management of the limited water resources allocated to agriculture.

Information concerning crop areas distribution and variability is becoming increasingly important for effective irrigation management. Remote sensing can resolve difficulties in determining and classifying crop types and acreage within irrigation schemes or at the water basin level.
Remote sensing imagery obtained during the growing season can be used to generate crop maps for both in-season irrigation management and off-season cropping management. Therefore, remote sensed images can be useful for addressing water and other production-related issues within the irrigation scheme. On top of that, crop classification maps will help managers and decision-makers to allocate sufficient water quantities to assure economic yields over large geographic areas within the irrigation scheme. However, despite the commercial availability and increased use of satellite images for crop classification, many water utilities managing irrigation schemes are not equipped with them. Partly for a lack of financial resources and also for a lack of skilled personnel in charge of analyzing the images and interpreting them into readable maps. 


\section{International Journal of Science and Research (IJSR) \\ ISSN (Online): 2319-7064 \\ Index Copernicus Value (2013): 6.14 | Impact Factor (2014): 5.611}

Remote sensing, particularly satellite images, offers an immense source of data for studying spatial and temporal variability of the environmental parameters [1]. Remote sensing has shown a great promise in identifying crops within an agricultural area or irrigation scheme. The resultant information has been found to be useful for cropping patterns and allocation of water resources for improved crop production [2], [3], [4]. Practical applications using airborne or space borne broadband imagery and narrowband hyperspectral data have been focused on irrigated land identification and land use/land cover classification [5], [6], [7], [8], [9], [10], [11], monitoring of crop biophysical features and growth performance [12], [13], [14], [15], [16], [17], estimation of the crop evapotranspiration (ET), water consumption and hydrological cycle [18], [19], [20], [21], and biomass production and yield [12], [22], [23], [24], [25], [26].

For water consumption estimation, it is necessary to understand where the land is irrigated. This can be achieved by classification on satellite and airborne images to identifythe irrigated land [5], [9], [11], [26], [27] or by simple logical operation in combination of vegetation indices such as NDVI with land surface temperature(LST) to separate irrigated from non-irrigated land [10]. This procedure allows one to understand the distribution of the irrigated cropland and other land use pattern, and crop performance, in which the results provide useful reference for farmers and decision-makers, as water allocation can be made based on the balance between the availability of water and demand of croplands and other land use [18], [28].

However, remote sensing processing and interpretation should be based on and validated by ground-truth data [15], [16], [17]. Thus, land use investigation and soil surveys can be very helpful to identifying crop signatures and understanding the causes of stresses, for example, disease, water-deficiency and soil salinity [16], [17]. Satellite imagery in conjunction with ground sampling provides a possibility for crop classification in large areas where a little or no information is available on crop variability. In addition, images acquired on different dates of a cropping season will allow us to explore the phonological features and changes of crops.
In this study, three RapidEye and three Landsat ETM+ satellite images acquired on different dates during the 2011 2012 growing years were used for a pilot area in the South Bekaa Irrigation Scheme (SBIS) in Lebanon. The aims were to analyze information from satellite images of varying spatial and temporal resolutions to derive crop maps and conduct intra-season and year-to-year monitoring to calculate the percentage change of crops in the growing years and assess irrigation water requirements at crop and the whole irrigation scheme levels for better water allocation strategies.

\section{Materials and Methods}

\subsection{Study Area}

The study site, a pilot area of 2000 ha, is located in the South Bekaa Valley in Lebanon and constitutes a part of the South Bekaa Irrigation Scheme (SBIS). The scheme is divided into three irrigation districts distributed on the left bank (6700 ha), right bank (9200 ha) and northern bank (5600 ha) of the Litani River, thus totaling 21500 ha of irrigated land (Figure 1a). In 1994 the Litani River Authority (LRA), the public water utility responsible for irrigation projects along the Litani River Basin, entered a new water dispensation, which saw the rehabilitation of existing irrigation schemes including SBIS. LRA realized the importance of conducting irrigation studies and awarded a tender to equip SBIS with a pressurized irrigation network. For economic constraints, only a pilot area of 2000 ha is for the time being equipped with a pressurized irrigation network, while the rest of the scheme is still relying on ground wells for irrigation purposes.

The pilot area is situated on the left bank of the Litani River and is inserted between the Canal 900 (900 $\mathrm{m}$ in average above the sea level) and the Litani River ( $860 \mathrm{~m}$ in average above the sea level). The pilot area is being supplied with water through the Canal 900 ,which is $18 \mathrm{~km}$ in length and gains water by pumping from the adjacent Qaraoun Lake (220 $\times 10^{6} \mathrm{~m}^{3}$ at full capacity). The irrigation pilot area is subdivided into three sub-sectors; K1 (257 ha), K2 (450 ha) and Joub Jennine (1293 ha), as indicated in Figure 1b, all being equipped with pressurized irrigation networks. 


\section{International Journal of Science and Research (IJSR) \\ ISSN (Online): 2319-7064}

Index Copernicus Value (2013): 6.14 | Impact Factor (2014): 5.611
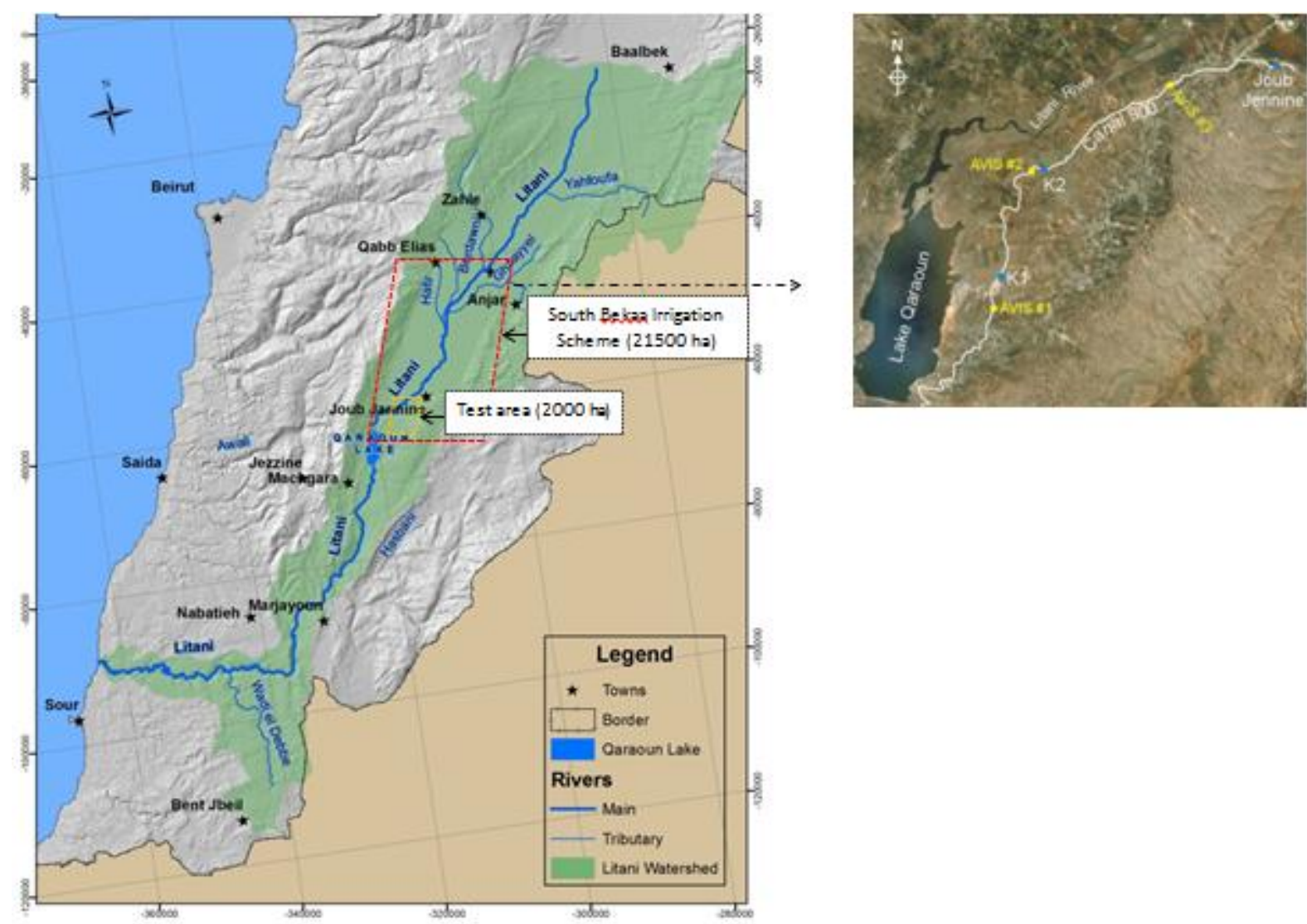

Figure 1(a): Geographic location of South Bekaa Irrigation Scheme (21500 ha) and the study test area (2000 ha), (b): Geographical location of Canal 900 irrigation conveyor (K1, K2, and Joub Jennine subsectors; AVIS stands for the canal flow control system).

The study area is characterized by a Mediterranean semi-arid climate, hot and dry from May to September, and cold and wet extending for the remainder of the year. Average seasonal rainfall is $850 \mathrm{~mm}$, with $95 \%$ of the rain recorded from October to May and only 5\% in April-May, calling most often for a drought during this period of the year, which coincides with the grain filling stage for wheat. No rain record in summer period in history (June - September). Generally, rain pattern shows a great year-to-year and monthly variability. In the 2010-2011 growing year, rain totaled $618 \mathrm{~mm}$ with $90 \%$ falling between October and March and 10\% in April-May; whereas in the 2011-2012 growing year,99\% of the total rain $(613 \mathrm{~mm})$ fell between October and March and only 1\% in April-May (Figure 2). Average annual potential evapotranspiration $\left(\mathrm{ET}_{\mathrm{p}}\right)$ as calculated by the FAO-modified Penman-Monteith equation [29] is $1185 \mathrm{~mm}$, justifying the need for irrigation during late spring and summer periods.
2010-2011 (617.6 mm; SD $67.5 \mathrm{~mm})$

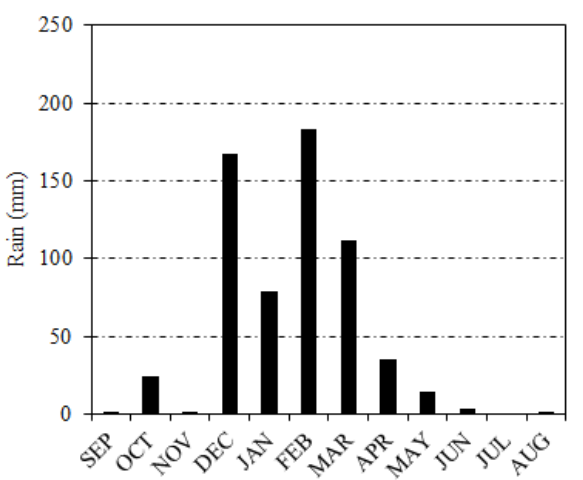

2011-2012 (613 mm; SD $69.1 \mathrm{~mm})$

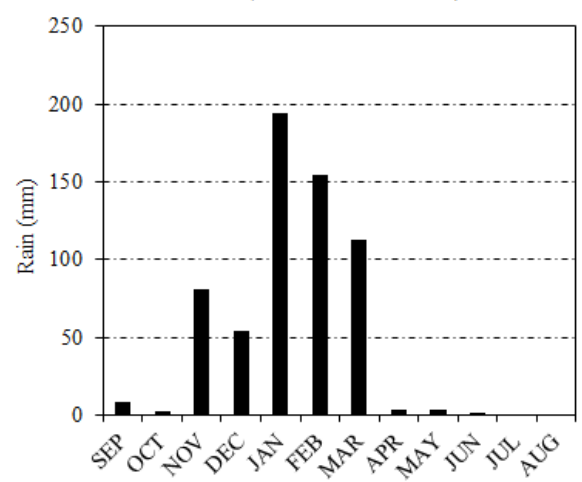

1990-2010 (850 mm; SD $72.2 \mathrm{~mm})$

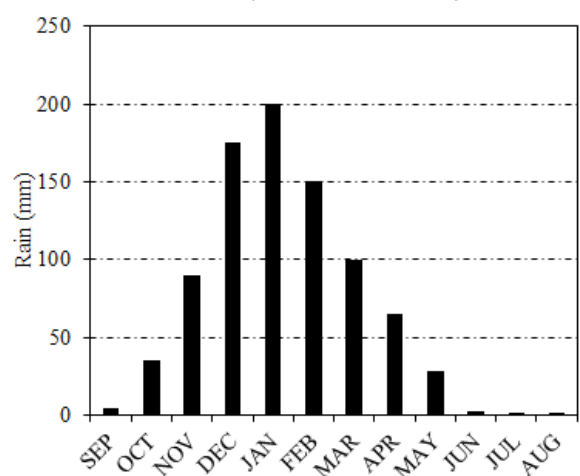


$2010-2011\left(15.5^{\circ} \mathrm{C} ; \mathrm{SD} 6.4^{\circ} \mathrm{C}\right)$

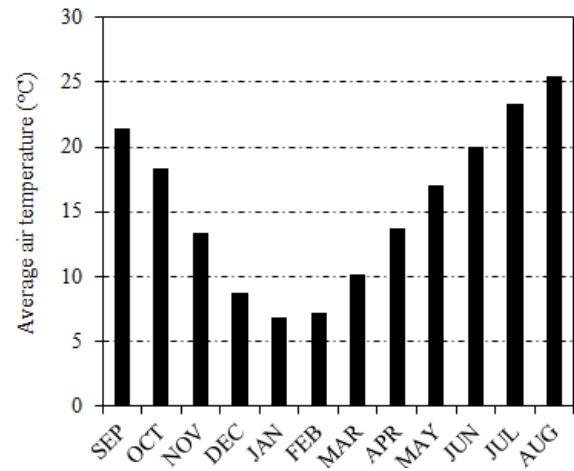

$2011-2012\left(13.4^{\circ} \mathrm{C} ; \mathrm{SD} 6.1^{\circ} \mathrm{C}\right)$

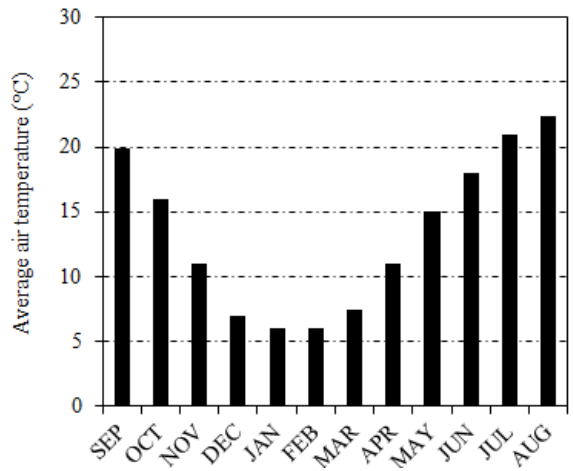

$1990-2010\left(14.7^{\circ} \mathrm{C} ; \mathrm{SD} 6.1^{\circ} \mathrm{C}\right)$

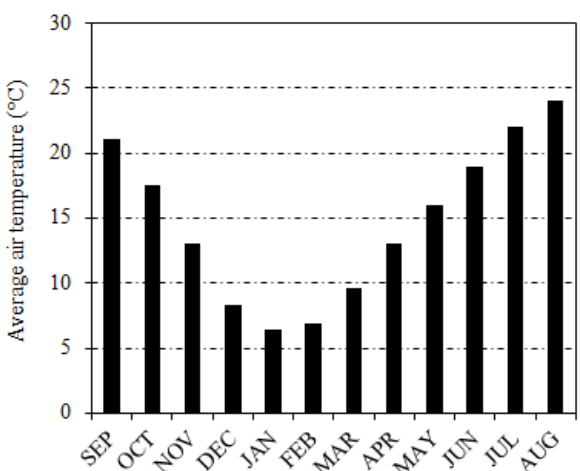

Figure 2: Monthly rain pattern and average air temperature during the surveyed growing years (2010-2011 and 2011-2012) compared to the long-run averages (1990-2010) recorded at Kherbet Kanafar Training and Extension Center $(\mathrm{SD}=\mathrm{Standard}$

Deviation).

Temperature is strongly seasonal, with frequent frost periods in winter time that markedly limit vegetation development and slow wheat growth. Average winter temperature is $10.8^{\circ} \mathrm{C}$, but minimum temperatures below $-5^{\circ} \mathrm{C}$ are common. Average temperature in summer is $25.8^{\circ} \mathrm{C}$, although maximum temperatures over $42^{\circ} \mathrm{C}$ are frequent [30]. The 2011-2012 growing year was somehow cooler than the 2010-2011 growing year. This was observed by the lowest average monthly air temperatures that were recorded in 2011-2012 compared to 2010-2011 (Figure 2). Soils in the study area are characterized by high clay content and relatively low organic matter. Field slope is less than $2 \%$ and totally available water within the top $100 \mathrm{~cm}$ of soil profile is $190 \mathrm{~mm} \mathrm{[30].}$
Agricultural land in the study area consists of one-third of wheat and other winter cereals, mainly barley, one-third of potato and summer vegetables and one third of fruit trees, olive and vineyard and land kept as fallow during the inbetween seasons [31]. Wheat receives supplemental irrigation in April-May, and often, but not always, followed in the same fields by late-sown potato in July. In some years, the land cropped with wheat is left as fallow in summer till the next wheat sowing time in autumn (October-November). Summer vegetables include tomatoes, green beans, watermelon, cucumbers and bell pepper. Fruit trees include apples and peaches. Table 1 summarizes the different cropping patterns that exist in the test area.

Table 1: Different cropping patterns that exist in the irrigated test area

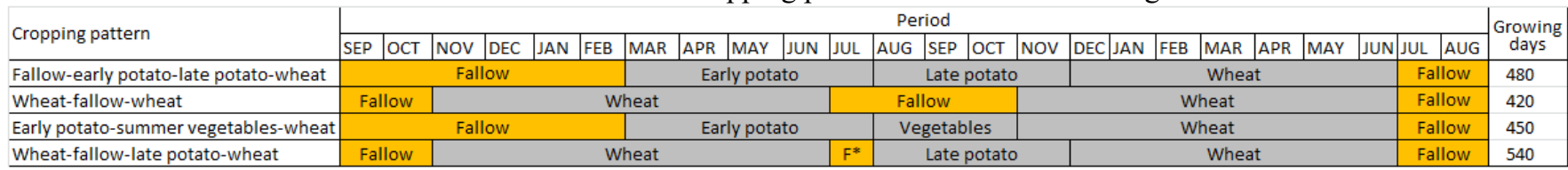

Usually, data of the irrigated areas per type of crop in the South Bekaa Irrigation Scheme can be obtained from the Litani River Authority Database (LRAD). However, LRAD is not often updated to permit an accurate estimation of crop types and acreage. This left farmers exposed to year-to-year fluctuations of supply and demand trends, which necessitated the requirement for more reliable crop production information. The Litani River Authority realized the importance of conducting accurate estimates of irrigated land per type of crop and conferred to the Litani River Basin Management Support Program (LRBMS), a five-year development program (2009-2014), the mandate to develop and implement a system to estimate cropped areas and forecast water allocation at yearly basis from the Canal 900 irrigation conveyor to irrigate cropland and increase yields based on a geographic point sampling frame that is stratified according to crop types and areas. A system was designed and implemented by LRBMS where satellite imagery was used as a first step to stratify the Upper Litani River Basin (ULRB) across the Bekaa Valley by separating all nonagricultural areas from agricultural areas. The agricultural areas were further classified into three crop categories: winter crops, spring and summer crops and fruit trees. A point grid was generated by LRBMS across the Upper Litani
River Basin, which was used for a geographic systematic random selection of points, with an increased sampling rate in higher cultivation areas. These selected points were surveyed by LRBMS field staff to gather information on crop types and areas planted. In combining and integrating satellite imagery, remote sensing and GIS, a downscale system was developed for the test area of 2000 ha over the command area of the Canal 900 irrigation conveyor to demonstrate the feasibility of such a method and further application within the South Bekaa Irrigation Scheme.

\subsection{Image processing and classification}

\subsubsection{Satellite imagery and field data}

The selection and acquisition of imagery were important to provide a solid foundation for crop classification within the test area. For this purpose, three RapidEye and three Landsat ETM+ images were acquired over the pilot area in May, July and September to detect the vegetation types and assess the soil occupancy (Table 2). The dates of images acquisition were carefully defined on the basis of crop calendars, provided by the Litani River Authority. 


\section{International Journal of Science and Research (IJSR) ISSN (Online): 2319-7064}

Index Copernicus Value (2013): 6.14 | Impact Factor (2014): 5.611

Table2: Dates of RapidEye and Landsat7ETM+images taken in this study.

\begin{tabular}{|c|c|}
\hline Date & Sensor \\
\hline 23 May 2011 & RapidEye \\
\hline 15July 2011 & RapidEye \\
\hline 26 September 2011 & RapidEye \\
\hline 6May 2012 & Landsat7ETM+ \\
\hline 9July 2012 & Landsat7ETM+ \\
\hline 27September 2012 & Landsat7ETM+ \\
\hline
\end{tabular}

RapidEye satellites provide multispectral images, which consist of five bands (three in the visible region - blue, green and red, one in the red edge and one in the near infrared regions). This product has a high spatial resolution $(5 \mathrm{~m})$, which enables to detect relatively small features on the ground. With this fine ground sampling, RapidEye constitutes a high potential for the application of agricultural monitoring [32]. With this fine ground sampling, RapidEye constitutes a high potential for the application of agricultural monitoring. However, given that its imagery only contains two bands in the infrared range, it restricts the differentiation between elements with characteristics that are similar to each other. For example, by using RapidEye images we can identify small planted areas, but we cannot neither distinguish between two types of fruit trees (e.g., apple and peach) nor use it for evapotranspiration (ET) estimation since there is no thermal band. This product was used in this study for the analysis during the 2011 cropping year.

Landsat7ETM+imagesprovide multispectral images that can be downloaded for free from the USGS server (http://glovis.usgs.gov/). Spectral bands include three in the visible range (blue, green, and red), one in the near-infrared, two in the mid-infrared, and two in the thermal infrared regions, and last, one panchromatic band. This product has a relatively lower spatial resolution (15-30 m), which prevents us from detecting small areas, but given its wider spectral coverage, it enables us to detect more different types [33], [34], [35]. This product was used for the analysis during the 2012 survey year.

RapidEye and Landsat data were considered suitable for this study as these satellites were designed mainly for monitoring agricultural and natural resources either based on multitemporaland time-seriesanalysis to understand land use dynamics and biophysical change in time or using classification-based techniques to quantify and qualify the land cover features of the observation time point [26], [27], [32], [36]. In addition, multi-temporal analysis based on several image acquisitions can serve to identify different croplands and also filter out the temporarily harvested agricultural fields or fallows in terms of the phonological cycles of crops. Other types of land such as forest, woodland, urban areas and water bodies, can be efficiently extracted from single RapidEye and Landsat ETM+ images by classification or decision-tree techniques.

In order to detect the different crop types and generate a signature for each crop type, we conducted pre-image acquisition field surveys to observe location and performance of different crops using a handheld Geographic Position System (GPS) device. In general, it is recommended to collect 3-4 field samples per type of crop to generate an accurate and comprehensive signature. However, as the study area had to be covered by multiple images taken at different dates, we decided to take an average of eight samples per crop type to guarantee the availability of field samples within all of these various images.

In this study, thirteen spectral classes including ten crop classes and three non-crop classes were defined based on the field survey and other ancillary data from the National Agricultural Census Database [37]. These data allowed us to categorize and identify the following classes of crops: (i) wheat, (ii) winter legumes, (iii) potatoes, (iv) summer vegetables, and (v) fruit trees. At this point we also made decisions on which classes can be grouped together into a single land use type. As a result, eight classes out of the ten identified agricultural classes were re-assigned to the eight major crops in the area (corn, field crops, fruit trees, olive, potato, tobacco, vineyard and wheat), while two classes were re-assigned to bareland that is uncropped land and land kept as fallow in the intra-season periods. Most of the bare areas included degraded soils and areas not accessible for agriculture. Crops with substantial overlap in the signature were grouped in the same spectral class. In the case of fruit trees the selected crops were apple and peach, while in the case of field crops they were bean, peas, lettuce, onion, and tomato. In addition, three classes namely urban, water and woodland were retained as non-agriculture classes. For the scope of this study, only those classes associated with crops were retained for analysis.

\subsubsection{Processing methodology}

The methodology used for generating crop coverage during the various images dates was the supervised classification of multispectral satellite images, which is one of the major techniques available in remote sensing [11], [27], [36], [38], [39], [40]. By using the supervised classification procedure, and selecting the maximum likelihood classifier, a zonal majority function can be used to assign a crop class to each field boundary polygon based on the raster classification. Ferreira et al. (2006) [38] have demonstrated that this procedure can give accurate results as per crop identification and classification, however, may contain confusion for land cover categories which are intergrading in spectral features, e.g., from urban to bareland [11]. Certain post-classification processing such as visual interpretation and re-allocation of the misclassified pixels to their proper classes is necessary [11]. Signature files can be generated for each cropland taking the phenology of each crop type into consideration.

The supervised classification involves first of all a selection and definition of appropriate training samples of particular signatures for different types of crop and other land cover. These signatures form a solid foundation for the subsequent crop classification [41]. The classification can be conducted on the whole images including all bands as input, or on a reasonable combination of bands, e.g., bands 7, 4 and 1 for Landsat TM and ETM+ imagery, because bands 1, 2 and 3 are correlated with each other and so are bands 5 and 7 [42]. To avoid information redundancy in bands and to save classification time, we can select one of the three bands in the visible region, one in the near infrared (i.e., band 4) and one in the shortwave spectral region (band 5 or 7) for this 


\section{International Journal of Science and Research (IJSR) \\ ISSN (Online): 2319-7064 \\ Index Copernicus Value (2013): 6.14 | Impact Factor (2014): 5.611}

purpose. It is also possible to choose the first three Principal Components (PCs), e.g., PC1, PC2 and PC3, to compose the most relevant band combination [42] to discriminate different crop types in the study area. Generally, the red band along with the infrared bands provides the strongest contrast in reflectance of vegetation and hence may facilitate the crop separation [15], [38]. In addition, the red edge band $(690-730 \mathrm{~nm})$ allows better estimation of the ground cover and chlorophyll content of the vegetation [43], [44], [45].

By overlapping field samples to the satellite images, the spectral signature for each crop type was then calculated based on the coincidence of these samples with the various available bands. Using the maximum likelihood classifier and combining the generated signatures as training areas, it was possible to classify the whole pilot site into the defined land cover classes. With this classification, images underwent a series of enhancement techniques to remove noises and cleanup the boundaries between adjacent areas of different types, and eventually convert different classes into vector polygons for further analysis and mapping. It is important to note that this methodology is based on a probabilistic approach and has to be repeated several times for each image until an accurate result is reached. An accurate result is defined as a result that matches $80 \%$ or more of the field samples [46].

After the supervised classification procedure, a zonal majority function can be applied to assign a crop type to each field boundary polygon. This step generated an ArcView shape file with a crop type for each field during a specific season for the study area, and even for the entire province if necessary, providing a basis for various queries and analysis.

\subsubsection{Statistical Tests}

Intra year and inter year comparisons of mapped irrigated areas of the various surveyed crops were made using the percent difference $\left(\mathrm{P}_{\mathrm{d}}\right)$ method [47]. This method is used to compare two quantities neither of which is known to be correct [48]. Equation 1 was used to calculate the percent difference:

$$
P_{d}=\left(\frac{\| A-B \rrbracket}{\| A+B \rrbracket \div 2}\right) \times 100
$$

Where A and B are the remotely sensed irrigated areas for a given crop class at two different dates. For inter year comparisons, , $\mathrm{A}^{\mathrm{ce}}$ and, $\mathrm{B}^{\mathrm{ec}}$ represent the remotely sensed irrigated areas in 2011 and 2012, respectively. For intra year comparisons, „A $\mathrm{A}^{\text {ee }}$ and, $\mathrm{B}^{\text {ce }}$ represent the remotely sensed irrigated areas of the different crops classes in two successive surveyed times: the first is May-July and the second July-September. As a result, a positive value obtained with equation (1) indicates an increase in the irrigated area, while a negative value indicates a decrease in the irrigated area.

\subsubsection{Accuracy determination}

Each classification test was evaluated in terms of overall accuracy (OA) and kappa coefficient, by comparing the reference data with the classified images, pixel by pixel [33] Despite the fact that both the OA and Kappa coefficient measure the agreement between the classified map and the reference data, Kappa is often considered a better indicator of classification performance because it excludes chance agreement [49]. Gonçalvez et al. (2007) [50] demonstrated that overall accuracy and kappa coefficient are common statistics used to validate remotely sensed data. In this study, we used both indicators to evaluate our classification results.

\subsection{Determination of irrigation water requirements}

Irrigation water requirements during the 2011-2012 growing seasons were estimated using the MOPECO model [51], which uses the methodology proposed by Allen et al. (1998) [29]. For the daily simulation of the soil-water balance, the model requires the reference evapotranspiration $\left(\mathrm{ET}_{\mathrm{o}}\right)$, the single crop coefficient $\left(\mathrm{K}_{\mathrm{c}}\right)$, the group of evapotranspiration, the soil properties as water content at field capacity and permanent wilting point, the root depth, the effective rainfall, and the irrigation schedule.

\subsubsection{Effective precipitation}

Effective rainfall $\left(\mathrm{P}_{\mathrm{e}}\right)$ was estimated by using the USDA "curve number 2 methodology" (NRCS, 2004). The curve number used was different according to the crop (Table 3), while the rest of parameters were: Hydrologic soil group "D"; "Good" hydrologic condition; and "Contoured labor" (land slope $<2 \%$ ).

Table 3: Crop parameters used by MOPECO for simulating the irrigation water requirements

\begin{tabular}{|c|c|c|c|c|c|c|c|c|c|c|c|c|c|c|}
\hline \multirow{2}{*}{ Crop } & $\begin{array}{c}\text { Start. } \\
\text { date }\end{array}$ & $\begin{array}{c}\text { Harv. } \\
\text { date }\end{array}$ & $\begin{array}{c}\text { Curve } \\
n b\end{array}$ & $\begin{array}{c}\text { ET } \\
\text { Group }\end{array}$ & $\begin{array}{c}K_{c} \\
\text { (initial) }^{3}\end{array}$ & $\begin{array}{c}K_{c} \\
(\text { mid })^{3}\end{array}$ & $\begin{array}{c}K_{c} \\
(\text { end })^{3}\end{array}$ & \multirow{2}{*}{$\begin{array}{c}\begin{array}{c}\text { Root } \\
\text { depth }^{3}\end{array} \\
(m)\end{array}$} & \multirow{2}{*}{\begin{tabular}{|c|}
$T_{U}$ \\
$\left({ }^{\circ} \mathrm{C}\right)$ \\
\end{tabular}} & $T_{L}$ & \multicolumn{4}{|c|}{ Duration $\left(G D D{ }^{\circ} C\right)^{18}$} \\
\hline & month & month & \multicolumn{2}{|c|}{ dimensionless } & \multicolumn{3}{|c|}{ dimensionless } & & & $\left({ }^{\circ} \mathrm{C}\right)$ & $\begin{array}{l}K_{c} \\
(I)\end{array}$ & $\begin{array}{l}K_{c} \\
(I I)\end{array}$ & $\begin{array}{c}K_{c} \\
(I I I)\end{array}$ & $\begin{array}{c}K_{c} \\
(I V)\end{array}$ \\
\hline Potato & Mar & July & 83 & $1^{1}$ & 0.45 & 1.05 & 0.75 & 0.6 & $26^{4}$ & $2^{4}$ & 170.9 & 487.1 & 1076.5 & 1661.1 \\
\hline Maize & May & Sept & 83 & $4^{1}$ & 0.30 & 1.20 & 0.60 & 1.7 & $30^{5}$ & $8^{5}$ & 189.5 & 551.7 & 1149.8 & 1588.7 \\
\hline Wheat & Nov & June & 83 & $3^{1}$ & 0.70 & 1.15 & 0.40 & 1.8 & $40^{17}$ & $6^{6}$ & 147.5 & 537.8 & 901.6 & 1359.9 \\
\hline Tobacco & June & Sept & 83 & $4^{1}$ & 0.35 & 1.10 & 1.10 & 0.6 & 35 & 15 & 196.2 & 609.7 & 748.6 & 875.2 \\
\hline Olive & April & Nov & 86 & $4^{1}$ & 0.65 & 0.70 & 0.70 & 1.7 & $40^{17}$ & $3.5^{7}$ & 312.1 & 1931.8 & 2955.1 & 3601.6 \\
\hline Grapes & April & Sept & 86 & $2^{1}$ & 0.30 & 0.70 & 0.45 & 2.0 & $40^{17}$ & $10^{8}$ & 92.7 & 633.3 & 1296.6 & 1638.6 \\
\hline Apple & April & Sept & 86 & $3^{1}$ & 0.45 & 0.95 & 0.70 & 2.0 & $36^{9}$ & $5^{9}$ & 179.6 & 1009.4 & 2250.5 & 2696.1 \\
\hline Peach & April & July & 86 & $3^{2}$ & 0.45 & 0.90 & 0.65 & 2.0 & $35^{10}$ & $7^{10}$ & 142.5 & 707.3 & 1665.9 & 2100.0 \\
\hline Bean & May & July & 83 & $3^{1}$ & 0.50 & 1.05 & 0.90 & 0.7 & $32^{11}$ & $5.1^{12}$ & 216.2 & 674.5 & 1207.2 & 1589.7 \\
\hline Peas & Mar & July & 83 & $2^{2}$ & 0.50 & 1.15 & 1.10 & 1.0 & $32^{13}$ & $-1.1^{12}$ & 308.2 & 738.4 & 1370.5 & 1728.1 \\
\hline Lettuce & April & June & 84 & $1^{2}$ & 0.70 & 1.00 & 0.95 & 0.5 & $22^{14}$ & $6^{14}$ & 125.7 & 405.8 & 590.8 & 732.8 \\
\hline Onion & April & Aug & 84 & $1^{1}$ & 0.70 & 1.05 & 0.75 & 0.6 & $40^{17}$ & $5^{15}$ & 105.4 & 320.0 & 1322.8 & 1975.4 \\
\hline Tomato & May & Aug & 84 & $2^{1}$ & 0.60 & 1.15 & 0.70 & 1.5 & $35^{16}$ & $7.3^{16}$ & 162.6 & 521.9 & 1148.5 & 1622.1 \\
\hline
\end{tabular}




\section{International Journal of Science and Research (IJSR) \\ ISSN (Online): 2319-7064 \\ Index Copernicus Value (2013): 6.14 | Impact Factor (2014): 5.611}

Where: $\mathrm{K}_{\mathrm{c}}$ (I): Initial; $\mathrm{K}_{\mathrm{c}}$ (II); Crop development; $\mathrm{K}_{\mathrm{c}}$ (III): Mid-season; $\mathrm{K}_{\mathrm{c}}$ (IV): Late season; $\mathrm{T}_{\mathrm{L}}$ : lower threshold temperature for development; $\mathrm{T}_{\mathrm{U}}$ : upper threshold temperature at which the rate of development begins to decrease; GDD: growing-degree-days; ${ }^{1}$ Danuso et al. (1995); ${ }^{2}$ Based on Doorenbos and Kassam (1979); ${ }^{3}$ Allen et al. (1998); ${ }^{4}$ Montoya (2013); ${ }^{5}$ López-Bellido (1991); ${ }^{6}$ Rawson et al. (2007); ${ }^{7}$ Bignami et al. (1999); ${ }^{8}$ WSU (2015); ${ }^{9}$ Lachapelle (2012); ${ }^{10}$ Marra et al. (2002); ${ }^{11}$ Hernandez-Armenta et al. (1989); ${ }^{12}$ Raveneau et al. (2011); ${ }^{13}$ SARE (2012); ${ }^{14}$ Brunini et al. (1976); ${ }^{15}$ Lancaster et al. (1996); ${ }^{16}$ Jaworski and Valli (1964); ${ }^{17}$ if the crop is not affected by $\mathrm{T}_{\mathrm{U}}$ a value equal to $40^{\circ} \mathrm{C}$ was considered, which is higher than the maximum temperature in the area; ${ }^{18}$ Lebanese Agricultural Research Institute (LARI).

\subsubsection{Reference evapotranspiration}

Reference evapotranspiration $\left(\mathrm{ET}_{\mathrm{o}}\right)$ was calculated using the model of FAO modified Penman-Monteith [29] at daily bases during the 2011-2012 growing seasons. Average monthly values of precipitation, barometric pressure, relative humidity, solar radiation, temperature, and wind speed data used to calculate reference evapotranspiration were obtained from the weather station of Kherbet Kanafar Training and Extension Center of Litani River Authority. The FAO modified Penman-Monteith model was shown to have a large application in arid and sub-humid areas [29].

\subsubsection{Crop evapotranspiration}

Daily $\mathrm{ET}_{\mathrm{m}}$ is calculated using the equation proposed by Doorenbos and Pruitt (1977) [52], which requires values for $\mathrm{K}_{\mathrm{c}}$ at each growth stage and daily reference evapotranspiration $\left(\mathrm{ET}_{\mathrm{o}}\right)$ [29] (Table 3).

$$
\mathrm{ET}_{\mathrm{m}}=\mathrm{K}_{\mathrm{c}} \times \mathrm{ET}_{\mathrm{o}}
$$

$\mathrm{ET}_{\mathrm{m}}$ and $\mathrm{ET}_{\mathrm{o}}$ are expressed in $\mathrm{mm} \mathrm{day}^{-1}$ and $\mathrm{K}_{\mathrm{c}}$ is dimensionless.

\subsubsection{Determination of the duration of the crop stages}

The climatic conditions of any particular year may affect the duration of days in the phenological stages. Thermal time expressed as accumulated growing-degree-days (GDD) is a widely used methodology [53]. To obtain the length of each growth stage in terms of GDD (Table 3), the double triangulation method [54] was used. This methodology requires the value of the lower threshold temperature for development $\left(\mathrm{T}_{\mathrm{L}}\right)$ and the upper threshold temperature at which the rate of development begins to decrease $\left(T_{U}\right)$ (Table 1). The development stages considered in this study were those corresponding to each $\mathrm{K}_{\mathrm{c}}$ stage: $\mathrm{K}_{\mathrm{c}}(\mathrm{I})$ : initial; $\mathrm{K}_{\mathrm{c}}$ (II): crop development; $\mathrm{K}_{\mathrm{c}}$ (III): mid-season; and $\mathrm{K}_{\mathrm{c}}$ (IV): late season [29]. The length of each stage was determined using experimental data conducted on the surveyed crops during the period of 1998-2009 at the Department of Irrigation and Agro-Meteorology of the Lebanese Agriculture Research Institute.

\subsubsection{Determination of net irrigation requirements}

Under no deficit irrigation conditions, the amount of irrigation water to be supplied to the crop is calculated by the model in order to maintain the soil moisture content between field capacity and the soil moisture content when the crop would be stressed by water deficit. The methodology used for determining the daily value of this point is described by Danuso et al. (1995) [55] and is based on the evapotranspiration group of the crop (Table 3), and the $\mathrm{K}_{\mathrm{c}}$ and $\mathrm{ET}_{\mathrm{o}}$ values.

Due to tree crops (grape, olive, apple, and peach) are irrigated using drip irrigation systems, a localization coefficient was included in the model. The value used by the model is the enclosed average of the values calculated by the methodologies proposed by Aljibury et al. (1974) [56]; Hoare et al. (1974) [57]; Keller and Karmeli (1974) [58]; Savva and Frenken (2002) [59]. The frame of plantation and the diameter of the top are the required data (Table 4).

Table 4: Localization coefficient $\left(\mathrm{K}_{1}\right)$ of tree crops

\begin{tabular}{|c|c|c|c|}
\hline Crop & $\begin{array}{c}\text { Top diameter } \\
(\mathrm{m})\end{array}$ & $\begin{array}{c}\text { Plantationframe } \\
(\mathrm{m} \times \mathrm{m})\end{array}$ & $\begin{array}{c}\mathrm{K}_{1} \\
(\text { dimensionless })\end{array}$ \\
\hline Olive & 3.00 & $7.0 \times 5.0$ & 0.31 \\
\hline Grapes & 0.75 & $2.8 \times 1.4$ & 0.23 \\
\hline Apple & 1.50 & $3.0 \times 3.0$ & 0.31 \\
\hline Peach & 1.00 & $3.0 \times 2.0$ & 0.25 \\
\hline
\end{tabular}

\subsubsection{Determination of gross irrigation requirements}

Net irrigation requirements (NIR) calculated by MOPECO for each crop and year were translated into gross irrigation requirements (GIR), which was obtained by dividing the net irrigation requirements (NIR) by irrigation efficiency at unit farm level $\left(\mathrm{E}_{\mathrm{u}}\right)$ :

$$
\operatorname{GIR}(\mathrm{mm})=\frac{\text { WIR }(\mathrm{mm})}{E_{\mathrm{si}}(\mathrm{gb})}
$$

$E_{u}$ is the product of the irrigation system efficiency $\left(E_{i s}\right)$, distribution uniformity (DU) and conveyance efficiency $\left(\mathrm{E}_{\mathrm{c}}\right)$. In the case of sprinkler irrigation, $\mathrm{E}_{\mathrm{u}}$ was equal to 0.70 (87\% of irrigation system efficiency, $85 \%$ of distribution uniformity and $95 \%$ of conveyance efficiency), while in the case of drip irrigation it was equal to 0.85 (95\% of irrigation system efficiency, $95 \%$ of distribution uniformity and $95 \%$ of conveyance efficiency) [60], [61], [62], [63].

Water demand (in $\mathrm{m}^{3}$ ) per crop was obtained by multiplying GIR (in $\mathrm{mm}$ ) by the area (in hectares) determined for each crop by the satellite imagery. Total water demand (in $\mathrm{m}^{3}$ ) within the test area was then obtained by summing up water demand of each individual crop and/or group of crops. Since "Fruit trees" and "Field crops" categories do not distinguish among individual crops, the main crops under these two categories were selected for determining NIR and GIR. For "Fruit trees" the selected crops were apple and peach, while for "Field crops" they were bean, peas, lettuce, onion, and tomato (Table 5). The percentage of each single crop within these two classes was determined as the ratio of the cultivated area of the crop over the total area of the crop class, both obtained from the FAOSTAT database for Lebanon [64]. 


\section{International Journal of Science and Research (IJSR) \\ ISSN (Online): 2319-7064 \\ Index Copernicus Value (2013): 6.14 | Impact Factor (2014): 5.611}

Table 5: Percentage of individual crops in the area of "Tree crops" and "Field crops" categories

\begin{tabular}{|c|c|c|c|}
\hline & & Area $^{\text {I }}$ (ha) & Percentage (\%) \\
\hline \multirow{3}{*}{ Fruit trees } & Apple & 14000 & 79.3 \\
\cline { 2 - 4 } & Peach & 3650 & 20.7 \\
\hline \multirow{4}{*}{$\begin{array}{c}\text { Field } \\
\text { crops }\end{array}$} & Bean (green) & 2550 & 17.9 \\
\cline { 2 - 4 } & Peas & 1000 & 7.0 \\
\cline { 2 - 4 } & Lettuce & 2800 & 19.6 \\
\cline { 2 - 4 } & Onion (dry) & 3400 & 23.9 \\
\cline { 2 - 4 } & Tomato & 4500 & 31.6 \\
\hline
\end{tabular}

FAOSTAT/Lebanon (2015).

\section{Results and Discussion}

\subsection{Image Crop Classification}

The results of the supervised crop classification in the surveyed periods are given in Table6. In order to understand the different cropping patterns that may occur in a given irrigation scheme, one should know the rotation of crops in the same patch of land. Satellite images taken at three different times of the growing season allowed us to identify twenty-six crop rotation patterns for the nine surveyed agricultural classes (corn, fallow, field crops, fruit trees, olive, potato, tobacco, vineyard and wheat), in addition to one for bareland and three for the non-agricultural classes (water, urban and woodland). Total imaged area was 2697.1 ha in 2011 and 2597.59 ha in 2012 (Table 6). The twenty-six crop rotation patterns identified in Table 6 represent the different agricultural combinations that may take place in the test area in the growing season. For example, early grown potato that is sown in March and harvested in July gives two different cropping combinations, which are potato-fallowfallow (combination 17) and potato-fallow-field crop (combination 18). Moreover, late-grown potato can follow early-grown potato in the same plot, giving thus other two crop rotation patterns, which are potato-potato-corn (combination 19) and potato-potato-fallow (combination 20).

The first results obtained for the test area indicate that both agricultural and non-agricultural features can be detected with high accuracy. For the test area, Table 6 shows that 445.30 ha $(16.5 \%)$ out of 2697.10 ha is non-agricultural land in 2011 , while it was 455.50 ha (17.5\%) out of 2597.59 ha in 2012. The potentially agricultural land accounts for $83.5 \%$ in 2011 and $82.5 \%$ in 2012.Bareland and woodland were correctly validated as non-agricultural areas and account for $14.2 \%$ and $3.9 \%$, respectively, in 2011 and $13.7 \%$ and $3.1 \%$, respectively, in 2012, of the total surveyed area.

By combining and summarizing the imaged crops and their cover areas in Table 6 , a table containing the total area of each crop can be generated for each surveyed period (Table 7). In 2011, the cultivated areas were 2259.9 ha in May, 2260.0 ha in July and 2235.5 ha in September, giving thus an average of 2251.8 ha, while in 2012 the cultivated areas were 2169.8 ha in May, 2122.0 ha in July and 2134.5 ha in
September, giving an average of 2142.09 ha. When we compare the percent difference $\left(\mathrm{P}_{\mathrm{d}}\right)$ values of the different surveyed features during the growing periods, nonagricultural features (bareland, water, urban and woodland) show no or very little change in land cover, while agricultural features show significant intra-season changes, except for fruit trees, olive and vineyard, where intra-season changes were reported null (Table 7). In the case of potato, being the most important crop in the study area, the percent difference values in May-July were $60.2 \%$ and $1.8 \%$ in 2011 and 2012, respectively. Based on $P_{d}$ values, we found that the overall classification for single years 2011 and 2012 was not significantly different from each other, but there were significant differences for all crop classifications in the different periods as shown in the inter-year comparisons in Table 7. From this table, a comparison made between years leads to observe that the cultivated areas in 2012 decreased by $3.0 \%, 4.8 \%$ and $3.4 \%$ in May, July and September, respectively, compared to the same periods in 2011. An average comparison made between the 2011 data versus data for the 2012 growing year shows a minor decrease of $3.8 \%$ of the cultivated land in 2011 compared to 2012 (Table 8). In addition, Table 8 demonstrated that average percentage of agricultural land over total land was $83.5 \%$ in 2011 and $82.5 \%$ in 2012 .

In both years, $27 \%$ of the surveyed area was land kept as fallow, while the percentage of bareland was 17\% (Figure 3 ). In 2011 , field crops occupied $14 \%$, followed by potatoes $(12 \%)$, vineyard $(10 \%)$, fruit trees $(8 \%)$, wheat $(7 \%)$ and corn $(2 \%)$. In 2012 , potato occupied $14 \%$, followed by vineyard $(11 \%)$, fruit trees $(9 \%)$, wheat $(9 \%)$ and $5 \%$ as corn, as shown in Figure 3.
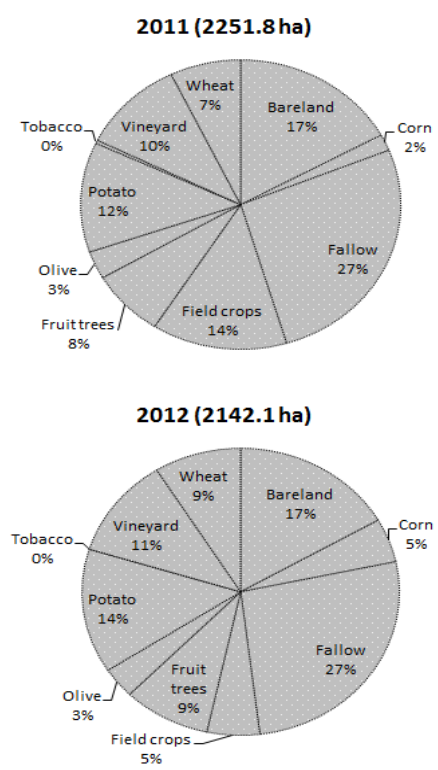

Figure 3: Comparison of agricultural land use in both surveyed years (2011 and 2012). 


\section{International Journal of Science and Research (IJSR) \\ ISSN (Online): 2319-7064}

Index Copernicus Value (2013): 6.14 | Impact Factor (2014): 5.611

Table 6: Results of the supervised crop classification

\begin{tabular}{|c|c|c|c|c|c|c|c|}
\hline \multirow{2}{*}{$\begin{array}{c}\text { Combination } \\
\text { Num. }\end{array}$} & \multirow{2}{*}{$\begin{array}{c}\text { Set } 1 \\
\text { (May-June) }\end{array}$} & \multirow{2}{*}{$\begin{array}{c}\text { Set } 2 \\
\text { (July-Aug) }\end{array}$} & \multirow{2}{*}{ Set 3 (Sept-Oct) } & Area (ha) & Cover (\%) & Area (ha) & Cover (\%) \\
\hline & & & & \multicolumn{2}{|c|}{2011} & \multicolumn{2}{|c|}{2012} \\
\hline 1 & Bareland & Bareland & Bareland $^{(1)}$ & 382.70 & 14.19 & 356.50 & 13.72 \\
\hline 2 & Corn & Corn & Fallow & 3.21 & 0.12 & 3.09 & 0.12 \\
\hline 3 & Fallow & Corn & Fallow & 9.61 & 0.36 & 9.26 & 0.36 \\
\hline 4 & Fallow & Fallow & Fallow & 146.99 & 5.45 & 121.44 & 4.68 \\
\hline 5 & Fallow & Fallow & Field Crop & 40.41 & 1.50 & 38.92 & 1.50 \\
\hline 6 & Fallow & Field Crop & Fallow & 36.90 & 1.37 & 35.54 & 1.37 \\
\hline 7 & Fallow & Field Crop & Field Crop & 99.93 & 3.71 & 96.26 & 3.71 \\
\hline 8 & Fallow & Potato & Fallow & 57.62 & 2.14 & 55.49 & 2.14 \\
\hline 9 & Fallow & Tobacco & Fallow & 1.27 & 0.05 & 1.23 & 0.05 \\
\hline 10 & Fallow & Tobacco & Field Crop & 4.49 & 0.17 & 4.32 & 0.17 \\
\hline 11 & Field Crop & Corn & Corn & 29.25 & 1.08 & 28.18 & 1.08 \\
\hline 12 & Field Crop & Corn & Fallow & 7.02 & 0.26 & 6.76 & 0.26 \\
\hline 13 & Field Crop & Fallow & Alfalfa & 78.37 & 2.91 & 75.49 & 2.91 \\
\hline 14 & Field Crop & Fallow & Fallow & 128.76 & 4.77 & 124.00 & 4.77 \\
\hline 15 & Fruit Tree & Fruit Tree & Fruit Tree & 168.58 & 6.25 & 190.30 & 7.33 \\
\hline 16 & Olive & Olive & Olive & 70.10 & 2.60 & 74.10 & 2.85 \\
\hline 17 & Potato & Fallow & Fallow & 2.42 & 0.09 & 2.33 & 0.09 \\
\hline 18 & Potato & Fallow & Field Crop & 2.93 & 0.11 & 2.82 & 0.11 \\
\hline 19 & Potato & Potato & Corn & 25.30 & 0.94 & 24.37 & 0.94 \\
\hline 20 & Potato & Potato & Fallow & 64.88 & 2.41 & 62.48 & 2.41 \\
\hline 21 & Tobacco & Tobacco & Fallow & 4.83 & 0.18 & 4.65 & 0.18 \\
\hline 22 & Tobacco & Tobacco & Field Crop & 4.71 & 0.17 & 4.54 & 0.17 \\
\hline 23 & Urban & Urban & Urban $^{(2)}$ & 335.20 & 12.43 & 368.40 & 14.18 \\
\hline 24 & Vineyard & Vineyard & Vineyard & 236.60 & 8.77 & 242.60 & 9.34 \\
\hline 25 & Water & Water & Water $^{(3)}$ & 4.70 & 0.17 & 6.40 & 0.25 \\
\hline 26 & Wheat & Corn & Corn & 8.02 & 0.30 & 7.72 & 0.30 \\
\hline 27 & Wheat & Corn & Fallow & 54.47 & 2.02 & 52.47 & 2.02 \\
\hline 28 & Wheat & Fallow & Fallow & 233.17 & 8.65 & 244.65 & 9.42 \\
\hline 29 & Wheat & Fallow & Potato & 349.24 & 12.95 & 272.60 & 10.49 \\
\hline 30 & Woodland & Woodland & Woodland $^{(4)}$ & 105.40 & 3.91 & 80.70 & 3.11 \\
\hline \multicolumn{4}{|c|}{ Total surveyed area } & $2,697.10$ & 100.00 & $2,597.59$ & 100.00 \\
\hline \multicolumn{4}{|c|}{ Area of agricultural combinations } & 2251.8 & 83.48 & 2142.09 & 82.46 \\
\hline \multicolumn{4}{|c|}{ Area of non-agricultural combinations } & 445.30 & 16.52 & 455.50 & 17.54 \\
\hline
\end{tabular}

(1), (2), (3), (4) are non-agricultural combinations

Table 7: Intra-year and inter-year crop changes in the test area as observed by RapidEye and Landsat7 ETM + during the 2011 and 2012 growing years, respectively

\begin{tabular}{|c|c|c|c|c|c|c|c|c|c|c|c|c|c|}
\hline \multicolumn{14}{|c|}{ Study area } \\
\hline \multirow[t]{2}{*}{ Class } & \multicolumn{5}{|c|}{$\begin{array}{l}\text { Intra-season comparisons (2011) } \\
(\mathrm{ha})\end{array}$} & \multicolumn{5}{|c|}{$\begin{array}{l}\text { Intra-season comparisons (2012) } \\
(\mathrm{ha})\end{array}$} & \multicolumn{3}{|c|}{$\begin{array}{c}\text { Inter-year comparisons } \\
(\%)\end{array}$} \\
\hline & MAY & JUL & SEP & MAY-JUL & JUL-SEP & MAY & JUL & SEP & $\begin{array}{c}\text { MAY- } \\
\text { JUL }\end{array}$ & \begin{tabular}{|l|} 
JUL- \\
SEP \\
\end{tabular} & MAY & JUL & SEP \\
\hline Bareland & 382.7 & 382.7 & 382.7 & 0.0 & 0.0 & 356.5 & 356.5 & 356.5 & 0.0 & 0.0 & -7.1 & -7.1 & -7.1 \\
\hline Corn & 3.5 & 63.5 & 57.6 & 178.9 & -9.6 & 0.0 & 72.2 & 247.1 & 200.0 & 109.5 & -200.0 & 12.9 & 124.3 \\
\hline Fallow & 418.0 & 587.7 & 787.9 & 33.7 & 29.1 & 135.2 & 678.7 & 887.0 & 133.6 & 26.6 & -102.2 & 14.4 & 11.8 \\
\hline Field crops & 251.9 & 138.0 & 531.0 & -58.4 & 117.5 & 199.9 & 96.7 & 47.2 & -69.6 & -68.8 & -23.0 & -35.2 & -167.4 \\
\hline Fruit trees & 169.7 & 169.7 & 169.7 & 0.0 & 0.0 & 190.3 & 190.3 & 190.3 & 0.0 & 0.0 & 11.4 & 11.4 & 11.4 \\
\hline Olive & 70.1 & 70.1 & 70.1 & 0.0 & 0.0 & 74.1 & 74.1 & 74.1 & 0.0 & 0.0 & 5.6 & 5.6 & 5.6 \\
\hline Potato & 237.3 & 596.3 & 0.0 & 86.1 & -200.0 & 403.5 & 410.9 & 89.8 & 1.8 & -128.3 & 51.9 & -36.8 & 200.0 \\
\hline Tobacco & 9.1 & 15.5 & 0.1 & 51.6 & -197.4 & 0.1 & 0.1 & 0.0 & 0.0 & -200.0 & -195.7 & -197.4 & -200.0 \\
\hline Vineyard & 236.6 & 236.6 & 236.6 & 0.0 & 0.0 & 242.6 & 242.6 & 242.6 & 0.0 & 0.0 & 2.5 & 2.5 & 2.5 \\
\hline Wheat & 481.0 & 0.1 & 0.1 & -199.9 & 0.0 & 567.8 & 0.1 & 0.1 & -199.9 & 0.0 & 16.5 & 0.0 & 0.0 \\
\hline Cultivated area (ha) & 2259.9 & 2260.0 & 2235.7 & 0.0 & -1.1 & 2169.9 & 2122.2 & 2134.6 & -2.2 & 0.6 & -4.1 & -6.3 & -4.6 \\
\hline Water & 4.7 & 4.7 & 4.7 & 0.0 & 0.0 & 6.4 & 6.4 & 6.4 & 0.0 & 0.0 & 30.6 & 30.6 & 30.6 \\
\hline Urban & 335.2 & 335.2 & 335.2 & 0.0 & 0.0 & 368.4 & 368.4 & 368.4 & 0.0 & 0.0 & 9.4 & 9.4 & 9.4 \\
\hline Woodland & 105.4 & 105.4 & 105.4 & 0.0 & 0.0 & 80.7 & 80.7 & 80.7 & 0.0 & 0.0 & -26.5 & -26.5 & -26.5 \\
\hline Total area $($ ha $)$ & 2705.2 & 2705.3 & 2681.0 & 0.0 & -0.9 & 2625.4 & 2577.7 & 2590.1 & -1.8 & 0.5 & -3.0 & -4.8 & -3.4 \\
\hline $\begin{array}{l}\text { Cultivated area as a } \\
\% \text { of total area }\end{array}$ & 83.5 & 83.5 & 83.4 & & & 82.7 & 82.3 & 82.4 & & & -1.1 & -1.5 & -1.2 \\
\hline
\end{tabular}

\section{Volume 5 Issue 1, January 2016}




\section{International Journal of Science and Research (IJSR) \\ ISSN (Online): 2319-7064}

Index Copernicus Value (2013): 6.14 | Impact Factor (2014): 5.611

Table 8: Summary of the comparisons of crop classification between 2011 and 2012

\begin{tabular}{|c|c|c|c|}
\hline & \multicolumn{3}{|c|}{ Inter-year comparison } \\
\hline Class & $\begin{array}{c}2011 \\
\text { (ha) }\end{array}$ & $\begin{array}{c}2012 \\
\text { (ha) }\end{array}$ & $\begin{array}{c}\text { Change (\%) } \\
\text { ( increase, - } \\
\text { decrease) }\end{array}$ \\
\hline Bareland & 382.7 & 356.5 & -7.1 \\
\hline Corn & 41.5 & 106.4 & 87.7 \\
\hline Fallow & 597.8 & 567.0 & -5.3 \\
\hline Field crops & 307.0 & 114.6 & -91.3 \\
\hline Fruit trees & 169.7 & 190.3 & 11.4 \\
\hline Olive & 70.1 & 74.1 & 5.6 \\
\hline Potato & 277.9 & 301.4 & 8.1 \\
\hline Tobacco & 8.2 & 0.1 & -196.8 \\
\hline Vineyard & 236.6 & 242.6 & 2.5 \\
\hline Wheat & 160.4 & 189.3 & 16.5 \\
\hline Cultivated area (ha) & 2251.9 & 2142.2 & -5.0 \\
\hline Water & 4.7 & 6.4 & 30.6 \\
\hline Urban & 335.2 & 368.4 & 9.4 \\
\hline Woodland & 105.4 & 80.7 & -26.5 \\
\hline Total area (ha) & 2697.2 & 2597.7 & -3.8 \\
\hline Cultivated area as a \% of & & & \\
total area & 83.5 & 82.5 & -1.2 \\
\hline
\end{tabular}

Figure 4 shows stacked images composed by different detected crop classes and taken at three consecutive periods across the growing season from May through October. Analysis of the stacked crop maps clearly highlights permanent bare areas, natural woodland and water bodies. The cropped areas appear to be either one of the eight crop classes or land kept as fallow in the intra-season periods in preparation of the next growing season. The latter represents $18.4,24.2$ and $33.1 \%$ of the cultivated area in May, July and September 2011, respectively, and $6.2,31.9$ and $36.8 \%$ in the same periods, respectively, in 2012. On the maps, the land kept as fallow appears in red color, while a light-brown color indicates potential bare areas, whereas pale yellow as corn, dense green as field crops, light violet as fruit trees, red as olive, dark brown as potato, light green as tobacco, dense violet as vineyard and earth color as wheat. Woodland appears in dense green color. Our results showed that the inclusion of all nine agricultural classes, along with the bareland class and non-agricultural classes versus land use resulted in almost identical maps (Figure 4).
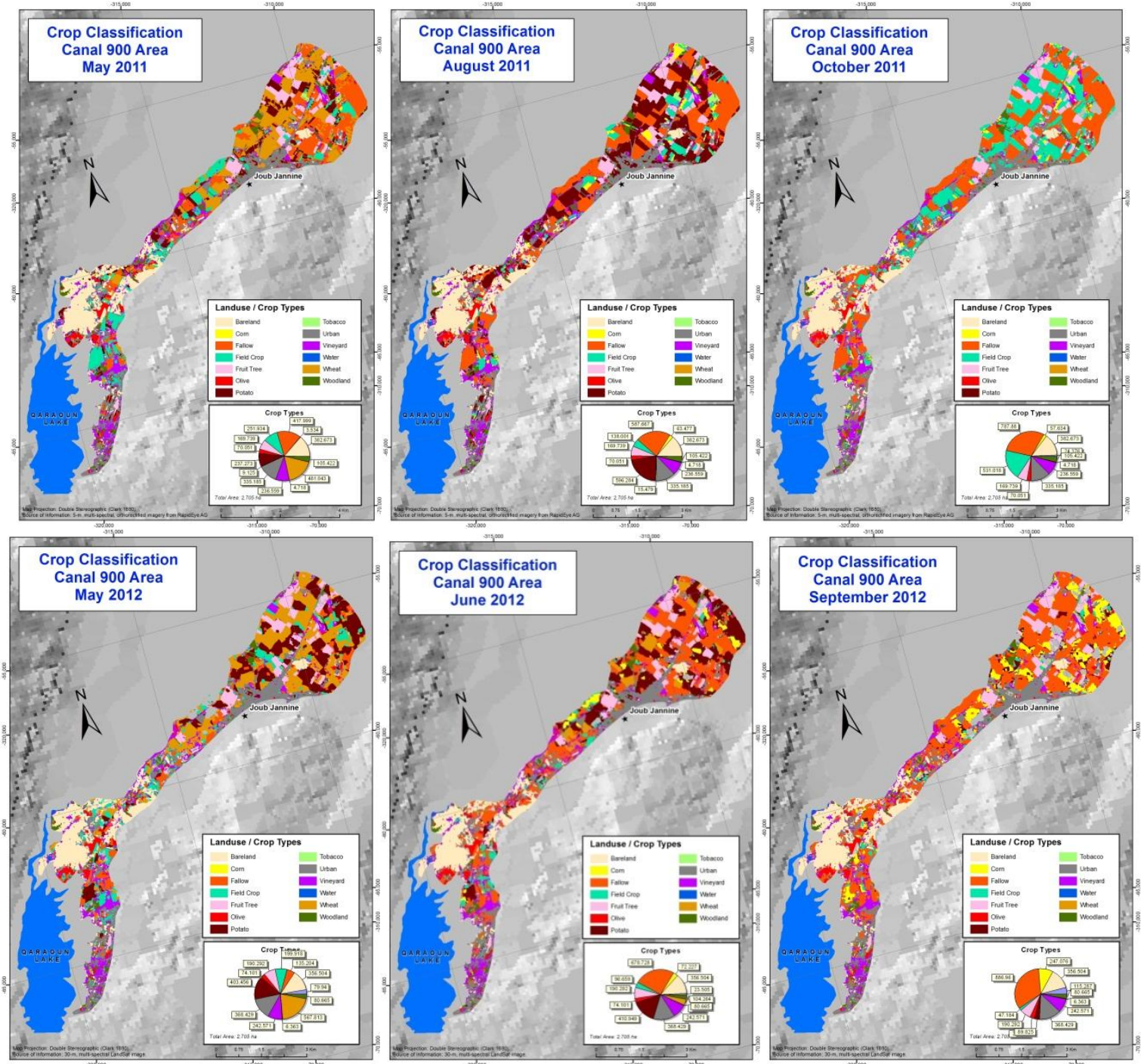

Figure 4: Maps showing temporal crop classification results in 2011 and 2012 growing years (crop type labels for real data: yellow $=$ corn, red $=$ fallow, dark green $=$ field crop, pink $=$ fruit trees, light red $=$ olive, brown $=$ potato, light green $=$ tobacco, violet $=$ vineyard, light brown $=$ wheat $)$.

Volume 5 Issue 1, January 2016 


\section{International Journal of Science and Research (IJSR) \\ ISSN (Online): 2319-7064 \\ Index Copernicus Value (2013): 6.14 | Impact Factor (2014): 5.611}

The results of the accuracy assessment of the classified maps, including overall accuracy (OA) and kappa coefficient, are presented in Table 9. As shown in this table, there was a good agreement between the classified maps and ground-truth data, which varied between $84 \%$ and $95 \%$ in overall accuracy, and between 0.71 and 0.91 in Kappa coefficient. We believe that our crop classification is of high reliability.

\subsection{Estimation of irrigation needs based on satellite images}

Table 10 shows irrigated crop areas in Canal 900 test area as determined by the remote sensing images, net irrigation requirements (NIR) and gross irrigation requirements (GIR) as simulated by MOPECO model during the 2011 and 2012 growing seasons. The simulations show that there were 5.16 $\mathrm{Mm}^{3}$ (million cubic meter) and $5.58 \mathrm{Mm}^{3}$ of water used to irrigate the remotely sensed 1271.3 ha and 1218.7 ha of cropland in the test area during the 2011 and 2012 growing seasons, respectively. The simulations also demonstrated that $28.4 \%$ and $32.6 \%$ of the simulated irrigation volume were used for potato in 2011 and 2012, respectively, while wheat consumptions were $12.2 \%$ and $18.6 \%$ of total water demand in 2011 and 2012, respectively. Simulations also showed that corn irrigation use has increased from $6 \%$ of total water demand in 2011 to $16.1 \%$ in 2012 , as the area cropped with corn increased by $87.7 \%$ in 2012 with comparison to 2011 (41.5 ha). In addition, table 10 demonstrates that gross irrigation requirements of field crops (beans, peas, lettuce, onion and tomatoes) decreased from $40 \%$ in 2011 to $18.3 \%$ in 2012 . This decrease in irrigation water demand was mainly due to a sharp decrease in the area cultivated with field crops from 307 ha in 2011 to 114.6 ha in 2012 , as marked in table 8 . The ratio of irrigation volume (in $\mathrm{m}^{3}$ ) to total irrigated area (in ha) gives the irrigation module (in $\mathrm{m}^{3} / \mathrm{ha}$ ), which equaled $4060.3 \mathrm{~m}^{3} / \mathrm{ha}$ in 2011 and $4579.4 \mathrm{~m}^{3} / \mathrm{ha}$ in 2012 , and both were lower than the irrigation module of $6500 \mathrm{~m}^{3} /$ ha set by the Litani River Authority.
Figure 5 compares simulated irrigation demand from the remotely sensed data and MOPECO model with that obtained by the Litani River Basin Database (LRAD) for Canal 900 test area during the 2011 and 2012 growing years. The comparison shows a good agreement between simulations and observations in 2011 but not in 2012 . Irrigation water demand obtained by LRAD was $5.74 \mathrm{Mm}^{3}$ in 2011 and $7.16 \mathrm{Mm}^{3}$ in 2012 , thus overestimating by $10 \%$ and $22 \%$ the simulated irrigation volumes by MOPECO in 2011 and 2012, respectively. Most probably the differences between simulations and observations that were found in 2012 may be caused by corn, the one cropped area increased remarkably in 2012 with comparison to 2011, thus increasing irrigation requirements by $65 \%$ in 2012 with comparison to 2011. Indeed, data reported by Litani River Authority observed $20 \%$ increase in total irrigation demand in 2012 with comparison to 2011 within Canal 900 test area. This increase might be attributed to the relatively high irrigation requirements of corn with comparison to other cultivated crops in the area. Karam et al. (2003) [65] demonstrated that corn seasonal evapotranspiration in the Bekaa Valley of Lebanon varies between 900 and $1000 \mathrm{~mm}$ for a growing season of 120-130 days from sowing till harvest. It is necessary therefore that farmers efficiently use water resources for irrigation of corn and other crops in South Bekaa Irrigation Scheme (SBIS) for better water supply-demand management.

Table 9: Overall accuracy and Kappa coefficient of each classification for both sensors according to the selected images

\begin{tabular}{|c|c|c|c|}
\hline Sensor type & Acquisition date & $\begin{array}{c}\text { Overall } \\
\text { accuracy (\%) }\end{array}$ & $\begin{array}{c}\text { Kappa } \\
\text { coefficient }\end{array}$ \\
\hline \multirow{3}{*}{ RapidEye } & 23 May 2011 & 87.80 & 0.7754 \\
\cline { 2 - 4 } & 15 July 2011 & 94.40 & 0.9005 \\
\cline { 2 - 4 } & $\begin{array}{c}\text { 26 September } \\
\text { 2011 }\end{array}$ & 85.40 & 0.7277 \\
\hline Landsat ETM+ & 6 May 2012 & 84.80 & 0.7155 \\
\cline { 2 - 4 } & 9 July 2012 & 95.20 & 0.9151 \\
\cline { 2 - 4 } & 27September & 84.40 & 0.7074 \\
\hline
\end{tabular}

Table 10: Irrigated crop areas in Canal 900 test area (ha) as determined by remote sensing images, net irrigation requirements (NIR) and gross irrigation requirements (GIR) as simulated by MOPECO model during the 2011 and 2012 growing seasons.

\begin{tabular}{|c|c|c|c|c|c|c|c|c|}
\hline & \multicolumn{2}{|c|}{ Area (ha) } & \multicolumn{2}{|c|}{ NIR (mm) } & \multirow{2}{*}{$\begin{array}{c}\mathrm{GIR}\left(\mathrm{m}^{3}\right) \\
2011\end{array}$} & \multicolumn{3}{|c|}{ Irrigation module $\left(\mathrm{m}^{3} / \mathrm{ha}\right)$} \\
\hline & 2011 & 2012 & 2011 & 2012 & & 2012 & 2011 & 2012 \\
\hline Corn & 41.5 & 106.4 & 629.1 & 846.2 & 308065.1 & 900328 & & \\
\hline Bean & 54.9 & 20.5 & 516.4 & 484.6 & 334786.9 & 138371.2 & & \\
\hline Peas & 21.5 & 8 & 383.8 & 328.8 & 97581.4 & 36813.9 & & \\
\hline Lettuce & 60.3 & 22.5 & 319.9 & 323.5 & 227685 & 101415.5 & & \\
\hline Onion & 73.2 & 27.3 & 743.9 & 860 & 643009.5 & 327410.7 & & \\
\hline Tomato & 96.9 & 36.2 & 685 & 827.1 & 783634.1 & 416756.4 & & \\
\hline Apple & 134.6 & 150.9 & 153.6 & 143.5 & 231600.4 & 286226.3 & & \\
\hline Peach & 35.1 & 39.4 & 99.9 & 98.3 & 39271.3 & 51137.3 & & \\
\hline Olive & 70.1 & 74.1 & 176.4 & 194 & 138464.1 & 189949.3 & & \\
\hline Potato & 277.9 & 301.4 & 446.7 & 434.3 & 1464736.3 & 1822656.8 & & \\
\hline Tobacco & 8.2 & 0 & 531.2 & 484 & 51397.2 & 0 & & \\
\hline Vineyard & 236.6 & 242.6 & 78.8 & 86.4 & 208724.7 & 277049.3 & & \\
\hline Wheat & 160.3 & 189.3 & 334.6 & 391.8 & 632845.5 & 1032825.2 & & \\
\hline & 1271.3 & 1218.7 & & & & & & \\
\hline Total water demand $\left(\mathrm{m}^{3}\right)$ & & & & & 5161801.4 & 5580940 & 4060.3 & $\overline{4579.4}$ \\
\hline
\end{tabular}




\section{International Journal of Science and Research (IJSR) ISSN (Online): 2319-7064}

Index Copernicus Value (2013): 6.14 | Impact Factor (2014): 5.611

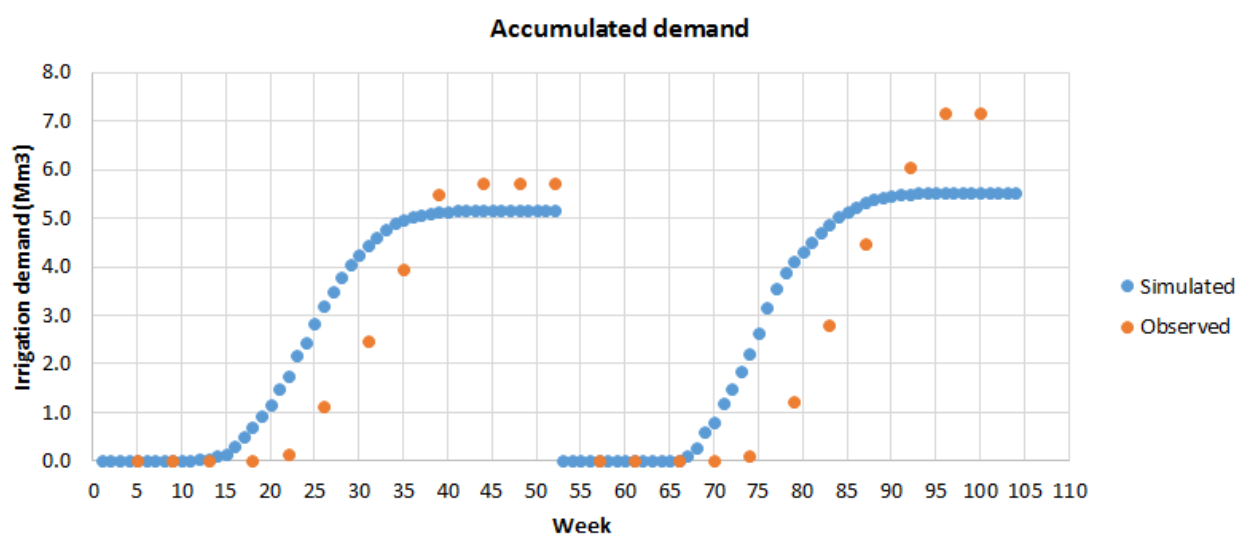

Figure 5: Comparison of observed and MOPECO simulated irrigation water use in 2011 and 2012 growing years

\section{Conclusions}

The methodology proposed in this paper offers a management tool for annual inventory and monitoring of cultivated lands in the test area within the South Bekaa Irrigation Scheme (SBIS). Using RapidEye and Landsat ETM + imagery, a supervised classification of multitemporal data was performed that quantified agricultural and non-agricultural areas at the growing seasons. Preliminary results clearly indicate that multi-temporal remote sensing classification can effectively contribute to differentiate between croplands and non-croplands, which are considered unsuitable for agriculture although further attempts to validate this methodology in other irrigation scheme is necessary.

Understanding the contribution of spatial and temporal monitoring of the vegetation variation is critical to estimate irrigation needs of the various crops within a given scheme. However, information on vegetation cover in the temporal dimension is most often unavailable. This approach provides a convenient pathway towards the discussion about a relevant crop classification plan in a given area. Such a plan may lead to a wealth of crop information within the temporal dimension, based on the understanding that remotely sensed spatio-temporal crop information is imperative for effective agricultural management.

Through integrating and combining remote sensing technology it was possible to identify crop type and cropped area estimates for the irrigation needs in a test area in the South Bekaa Irrigation Scheme, while generating multitemporal maps showing the spatial distribution of crop type patterns. It was thus possible to extract information on the irrigation requirements of the different mapped crops within the test area. This provides decision-makers with possibilities of spatial analysis, which were not previously available for the water utility. It was concluded that remote sensing images serve as trustable information for decisionmaking related to crops monitoring and mapping over a preselected test area. Even though multispectral images give details on the overall vegetation map in the given area [66], this technique is still having a limitation use due to the broad wavelength and spatial resolution that imped us differentiating crops of similar type. In that specific case, hyperspectral images would perform better as they contain more concrete and detailed spectral signature [67] and their higher spatial resolutions may enable greater distinction of vegetation classes [48], [68], [69].

Results obtained in this study showed that it is possible to map agriculture for small areas using RapidEye $(5 \mathrm{~m})$ and Landsat $(30 \mathrm{~m})$ data with overall accuracies of about 84 $95 \%$. In addition, our results showed that water demand can be decreased by $10-22 \%$ when remote sensing data are used. This represents a significant saving portion of the water resources that are allocated for irrigation purposes and can be used to bring additional land into irrigation within the scheme.

We concluded that multi-temporal crop classification and mapping provides spatially explicit information of crop rotation and crop area data. This approach demonstrates the importance of spatial processes in determining water allocation in a given irrigation scheme, and in assisting decision-making of accounting for the quantity of seasonal water requirements that should be allocated by the irrigation system. A further validation of the results is planned with more reliable ground truth data, available from the annual field inspection conducted by the Litani River Authority in the selected agriculture parcels from the South Bekaa Irrigation Scheme.

\section{Acknowledgements}

Authors wish to thank the US Agency for International Development (USAID) for sponsoring the Litani River Basin Management Support (LRBMS) Program (20092013). Special thanks are due to International Resources Group (Engility) for technical support. Finally, authors wish to address special thanks to Mr. Eric Viala, Chief of Party of LRBMS for his enduring support and valuable contribution all through the project.

\section{References}

[1] K. Perumal, R. Bhaskaran, "Supervised classification performance of multispectral images," Journal of Computing, 2 (2), pp. 124-129, 2010.

[2] M.S. Moran, Y. Inoue, E.M. Barnes, "Opportunities and limitations for image-based remote sensing in precision crop management," Remote Sensing of Environment, 61, pp. 319-346, 1997. 


\section{International Journal of Science and Research (IJSR) \\ ISSN (Online): 2319-7064 \\ Index Copernicus Value (2013): 6.14 | Impact Factor (2014): 5.611}

[3] M.D. Nellis, K.P. Price, D. Rundquist, "Remote Sensing of Cropland Agriculture," Papers in Natural Resources, Paper 217, 2009. (http://digitalcommons.unl.edu/natrespapers/217)

[4] J.P.J. Pinter, J.L. Hatfield, J.S. Schepers, E.M. Barnes, M.S. Moran, C.S.T. Daughtry, D.R. Upchurch, "Remote Sensing for Crop Management," Photogrammetric Engineering \& Remote Sensing, 69 (6), pp. 647-664, 2003.

[5] C. Alcantara, T. Kuemmerle, A.V. Prishchepov, V.C. Radeloff, "Mapping abandoned agriculture with multitemporal MODIS satellite data," Remote Sensing of Environment, 124, pp. 334-347, 2012.

[6] T. Blaschke, "Object based image analysis for remote sensing," ISPRS Journal of Photogrammetry and Remote Sensing, 65, pp. 2-16, 2010.

[7] M.A. Friedl, D.K. McIver, J.C.F. Hodges, X.Y. Zhang, D. Muchoney, A.H. Strahler, C.E. Woodcock, S. Gopal, A. Schneider, A. Cooper, A. Baccini, F. Gao, C. Schaaf, "Global land cover mapping from MODIS: algorithms and early results," Remote Sensing of Environment, 83, pp. 287-302, 2002.

[8] P.S. Thenkabail, E.A. Enclona, M.S. Ashton, B. Van Der Meer, "Accuracy assessments of hyperspectral waveband performance for vegetation analysis applications," Remote Sensing of Environment, 91 (34), pp. 354-376, 2004.

[9] M. Volpi, G.P. Petropoulos, M. Kanevski, "Flooding extent cartography with Landsat TM imagery and regularized kernel Fisher's discriminant analysis," Computers \& Geosciences, 57, pp. 24-31, 2013.

[10] W. Wu, E. De Pauw, "A simple algorithm to identify irrigated croplands by remote sensing," Proceedings of the $34^{\text {th }}$ International Symposium on Remote Sensing of Environment, Sydney, Australia, 2011. (www.isprs.org/proceedings/2011/isrse34/211104015Final00930.pdf).

[11] W. Wu, W. Zhang, "Present land use and cover patterns and their development potential in North Ningxia, China," Journal of Geographical Sciences, 13 (1), pp. 54-62, 2003.

[12] M.S. Seidl, W.D. Batchelor, J.O. Paz, "Integrating remotely sensed images with a soybean model to improve spatial yield simulation," Transactions of the American Society of Agricultural Engineers, 47 (6), pp. 2081-2090, 2004.

[13] S.M. Vicente-Serrano, C. Gouveia, J.J. Camarero, S. Beguería, R. Trigo, J.I. López-Moreno, C. AzorínMolina, E. Pasho, J. Lorenzo-Lacruz, J. Revuelto, E. Morán-Tejeda, A. Sanchez-Lorenzo, "Response of vegetation to drought time-scales across global land biomes," Proceedings of the National Academy of Sciences of the United States of America, 110, pp. 5257, 2013.

[14] S.M. Vicente-Serrano, F. Pérez-Cabello, T. Lasanta, "Assessment of radiometric correction techniques in analyzing vegetation variability and change using time series of Landsat images," Remote Sensing of Environment, 112, pp. 3916-3934, 2008.

[15] W. Wu, "The generalized difference vegetation index (GDVI) for dryland characterization," Remote Sensing, 6, pp. 1211-1233, 2014.
[16] W. Wu, W.M. Al-Shafie, A.S. Mhaimeed, F. Ziadat, V. Nangia, W.B. Payne, "Soil salinity mapping by multiscale remote sensing in Mesopotamia, Iraq," IEEE Journal of Selected Topics in Applied Earth Observations and Remote Sensing, 7 (11), pp. 44424452, 2014a.

[17] W. Wu, A.S. Mhaimeed, W.M. Al-Shafie, F. Ziadat, B. Dhehibi, V. Nangia, E. De Pauw, "Mapping soil salinity changes using remote sensing in Central Iraq," Geoderma Regional, 2-3, pp. 21-31, 2014b.

[18]P. Karimi, W.G.M. Bastiaanssen, D. Molden, M.J.M Cheema, "Basin-wide water accounting using remote sensing data: the case of transboundary Indus Basin," Hydrology Earth System Sciences Discussions, 9, pp. 12921-12958, 2012.

[19] M.F. McCabe, E.F. Wood, R. Wójcik, M. Pan, J. Sheffield, H. Gao, M. Su, "Hydrological consistency using multi-sensor remote sensing data for water and energy cycle studies," Remote Sensing of Environment, 112 (2), pp. 430-444, 2008.

[20] C.M.U. Neale, H. Jayanthi, J.L. WrightJL, "Irrigation water management using high resolution airborne remote sensing," Irrigation and Drainage Systems, 19 (3-4), pp. 321-336, 2005.

[21] J.A. Sobrino, M. Gómez, J.C. Jiménez-Muñoz, A. Olioso, «Application of a simple algorithm to estimate daily evapotranspiration from NOAA-AVHRR images for the Iberian Peninsula" Remote Sensing of Environment, 110, pp. 139-148, 2007.

[22] P.C. Doraiswamy, S. Moulin, P.W. Cook, A. Stern, "Crop Yield Assessment from Remote Sensing," Photogrammetric Engineering \& Remote Sensing, 69 (6), pp. 665-674, 2003.

[23] L. Serrano, I. Filella, J. Penuelas, "Remote sensing of biomass and yield of winter wheat under different Nitrogen supplies," Crop Science, 40, pp. 723-731, 2000.

[24] R. Teal, B. Tubana, K. Girma, K. Freeman, D. Arnall, O. Walsh, W. Raun, "In season prediction of corn grain yield potential using normalized difference vegetation index," Agronomy Journal, 98, pp. 1488-1494, 2006.

[25]P.M. Teillet, A. Chichagov, G. Fedosejevs, R.P. Gauthier, G. Ainsley, M. Maloley, M. Guimond, C. Nadeau, H. When, A. Shankaie, J. Yang, M. Cheung, A. Simth, G. Bourgeois, R. de Jong, V.C. Tao, S.H.L. Liang, J. Freemantle, "An integrated Earth sensing sensor web for improved crop and yield predictions," Canadian Journal of Remote Sensing, 33 (2), pp. 88-98, 2007.

[26] W. Wu, E. De Pauw, U. Hellden, “Assessing woody biomass in African tropical savannahs by multiscale remote sensing," International Journal of Remote Sensing, 34, pp. 4525-4529, 2013a. DOI:10.1080/01431161.2013.777487.

[27] W. Wu, E. De Pauw, C. Zucca, "Using remote sensing to assess impacts of land management policies in the Ordos rangelands in China," International Journal of Digital Earth, 6, pp. 81-102, 2013b. DOI: 10.1080/17538947.2013.825656.

[28]D. Molden, "Accounting for water use and productivity," SWIM Paper 1, International Irrigation Management Institute (ISBN 92-9090-349 X), Colombo, Sri Lanka, 1997. 


\section{International Journal of Science and Research (IJSR) \\ ISSN (Online): 2319-7064}

Index Copernicus Value (2013): 6.14 | Impact Factor (2014): 5.611

[29] R.G. Allen, L.S. Pereira, D. Raes, M. Smith, "Crop Evapotranspiration: Guide-lines for Computing Crop Water Requirements," Irrigation and Drainage Paper 56, Food and Agriculture Organization of the United Nations (FAO), Rome, Italy, 1998.

[30]F. Karam, J. Breidy, C. Stephan, J. Rouphael, "Evapotranspiration, yield and water use efficiency of drip irrigated corn in the Bekaa Valley of Lebanon," Agric. Water Manag., 63, pp. 125-137, 2003.

[31]F. Karam, K. Karaa, "Recent trends in the development of a sustainable irrigated agriculture in the Bekaa valley of Lebanon," Options Méditerranéennes, 31, pp. 65-86, 2000.

[32]B. Tapsall, P. Milenov, K. Taşdemir, "Analysis of RapidEye imagery for annual land cover mapping as an Aid to European Union (EU) common agricultural policy," in ISPRS TC VII Symposium-100 Years ISPRS, W. Wagner and B. Székely (eds.), Vienna, Austria, IAPRS, 38 (7B), pp. 568-573, 2010.

[33]D. Qinghan, E. Herman, C. Zhongxin, "Crop area assessment using remote sensing on the North China plain," The International Archives of the Photogrammetry, Remote Sensing and Spatial Information Sciences, 37 (B8), pp. 957-962, 2008.

[34] S. Siachalou, G. Mallinis, M. Tsakiri-Strati, "A hidden Markov models approach for crop classification: linking crop phenology to time series of multi-senor remote sensing data," Remotesens, 7, pp. 3633-3650, 2015. DOI: $10.3390 /$ rs 70403633 .

[35] P.S. Thenkabail, "Biophysical and yield information for precision farming from near-real-time and historical Landsat TM images," International Journal of Remote Sensing, 24 (14), pp. 2879-2904, 2003.

[36] W. Wu, "Monitoring land degradation in drylands by remote sensing," in Desertification and Risk Analysis Using High and Medium Resolution Satellite Data, A. Marini, M. Talbi (eds.), Springer, pp. 157-169, 2009.

[37] MOA/FAO, "Results of the National Agricultural Census. Project UTF/LEB/016. Assistance to Agricultural Census," Ministry of Agriculture (MOA) and Food and Agriculture Organization of the United Nations (FAO), Beirut, Lebanon, 2000.

[38] S.L. Ferreira, T. Newby, E. du Preez, "Use of remote sensing in support of crop area estimates in South Africa," in ISPRS Archives XXXVI-8/W48 Workshop proceedings: Remote sensing support to crop yield forecast and area estimates, pp. 51-52, 2007.

[39] L.F. Johnson, D.E. Roczen, S.K. Youkhana, R.R. Nemani, D.F. Bosch, "Mapping vineyard leaf area with multispectral satellite imagery," Computers and Electronics in Agriculture, 38, pp. 33-44, 2003.

[40] Y. Peng, R. Lu, "Anlctf-based multispectral imaging system for estimation of apple fruit firmness: Part II. Selection of optimal wavelengths and development of prediction models," Transactions of the ASABE, 49 (1), pp. 269-275, 2006. DOI: 10.13031/2013.20224.

[41] R.K. Dhumal, Y. Rajendra, K.V. Kale, S.C. Mehrotra, "Classification of Crops from remotely sensed Images: An overview," International Journal of Engineering Research and Applications (IJERA), 3 (3), pp. 758-761, 2013.

[42] W. Wu, "Application de la géomatique au suivi de la dynamique environnementale en zones arides," $\mathrm{PhD}$ dissertation (in French), Université de Paris I (PanthéonSorbonne), 2003.

[43] D. Haboudane, J.R. Miller, N. Tremblay, P.J. ZarcoTejada, L. Dextraze, "Integrated narrow-band vegetation indices for prediction of crop chlorophyll content for application to precision agriculture," Remote Sensing of Environment, 81 (2), pp. 416-426, 2002.

[44]A. Viña, A.A. Gitelson, "New developments in the remote estimation of the fraction of absorbed photo synthetically active radiation in crops," Geophysical Research Letters, 32, L17403, 2005. DOI:10.1029/2005GL023647.

[45] A. Viña, A.A. Gitelson, D.C. Rundquist, G. Keydan, B. Leavitt, J. Schepers, "Monitoring Maize (Zea mays L.) Phenology with Remote Sensing," Agronomy Journal, 96, pp. 1139-1147, 2004.

[46]F.S. Erbek, C. Özkan, M. Taberner, "Comparison of maximum likelihood classification method with supervised artificial neural network algorithms for land use activities," International journal of remote sensing, 25 (9), pp. 1733-1748, 2004.

[47] University of California, Davis, "Percent Error and Percent Difference described," Physics Lab 9, 2002. (http://www.physics.ucdavis.edu/Classes/Physics9Lab/P hy9CLab/-9ASupplements.pdf)

[48] J.R. Masoner, C.S. Mladinich, A.M. Konduris, S.J. Smith," Comparison of irrigation water use estimates calculated from remotely sensed irrigated acres and State reported irrigated acres in the Lake Altus Drainage Basin, Oklahoma and Texas, 2000 growing season," US Geological Survey and Bureau of Reclamation of the US Department of the Interior, 38p, 2003.

[49] R.G. Congalton, "A review of assessing the accuracy of classifications of remotely sensed data," Remote sensing of Environment, 49 (12), pp. 1671-1678, 1991.

[50]R.P. Gonçalvez, L.C. Assis, C.A.O. Vieira, " Comparison of sampling methods to classification of remotely sensed images," in IV Simpósio Internacional de Agricultura de Precisăo, Viçosa-MG, 2007.

[51] A. Domínguez, J.M. Tarjuelo, J.A. de Juan, E. LópezMata, J. Breidy, F. Karam, "Deficit irrigation under water stress and salinity conditions: The Mopeco-salt model,” Agric. Water Manag., 98, pp. 1451-1461, 2011.

[52] J. Doorenbos, W.O. Pruit, "Guidelines for predicting crop water requirements," Irrigation and Drainage Paper 24, Food and Agriculture Organization of the United Nations, Rome, Italy, 1977.

[53] D.C. Nielsen, S.E. Hinkle, "Field evaluation of basal crop coefficients for corn based on growing degree days, growth stage, or time," Transactions of the ASAE, 39, pp. 97-103, 1996.

[54] V. Sevacherian, V.M. Stern, A.J. Mueller, "Heat accumulation for timing Lygus control pressures in a safflower-cotton complex," Journal of Economic Entomology, 70, pp. 399-402, 1977.

[55]F. Danuso, M. Gani, R. Giovanardi, "Field water balance: Bidri Co 2," in L.S. Pereira, B.J. Van Der Broeck, P. Kabat, R.G. Allen (eds.), Crop-WaterSimulation Models in Practice, ICI-CIID, SC-DLO. Wageningen Pres. Wageningen, The Netherlands, 1995.

[56]F.K. Aljibury, W. Marsha, J. Huntamer, "Water use with drip irrigation," Proceedings of the Second 
International Drip Irrigation Congress, pp. 341-345, 1974.

[57] E.R. Hoare, K.V. Garzoli, J. Blackwell, "Plant water requirements as related to trickle irrigation," In Proceeding of Second International Drip Irrigation Congress, San Diego, CA, pp. 323-328, 1974.

[58] J. Keller, D. Karmeli, "Tricle irrigation design parameters," ASAE Transactions, 17 (4), pp. 678-684, 1974.

[59] A.P. Savva, K. Frenken, "Irrigation manual. Planning, development monitoring and evaluation of irrigated agriculture with farmer participation. Vol. IV," Food and Agriculture Organization of the United Nations (FAO) and Sub-regional Office for East and Southern Africa (SAFR), Harare, Zimbabwe, 2002.

[60]A. Capra, B. Scicolone, "Water Quality and Distribution Uniformity in Drip/Trickle Irrigation Systems," Journal Agriculture Engineering Research, 70 (4), pp. 355-365, 1998.

[61]F. Karam, R. Saliba, S. Skaf, J. Breidy, Y. Rouphael, J. Balendonck, "Yield and water use of eggplants (Solanummelongena L.) under full and deficit irrigation regimes," Agric. Water Manag., 98, pp. 1307-1316, 2011.

[62] J.M. Tarjuelo, J. Montero, M. Valiente, F. Honrubia, J. Ortiz, "Irrigation uniformity with medium size sprinklers. Part II. Influence of wind and other factors on water distribution," Transactions of the ASAE, 42 (3), pp. 677-689, 1999.

[63] J.M. Tarjuelo, J.F. Ortega, J. Montero, J.A. De Juan, "Modeling evaporation and drift losses in irrigation with medium size impact sprinklers under semi-arid conditions," Agric. Water Manag., 43, pp. 263-284, 2000.

[64]FAOSTAT, "Food and agriculture organization of the United Nations," Statistics division, 2015. [On line] http://faostat3.faor.org/home/E

[65]F. Karam, J. Breidy, C. Stephan, J. Rouphael, "Evapotranspiration, yield and water use efficiency of drip irrigated corn in the Bekaa Valley of Lebanon," Agric. Water Manag., 63, pp. 125-137, 2003.

[66] R.K. Dhumal, Y. Rajendra, K.V. Kale, S.C. Mehrotra, "Classification of Crops from remotely sensed Images: An overview," International Journal of Engineering Research and Applications (IJERA), 3 (3), pp. 758-761, 2013.

[67]B.D. Jadhav, P.M. Patil, "Hyperspectral Remote Sensing For Agricultural Management: A Survey," International Journal of Computer Applications, 106 (7), pp. 38-43, 2014.

[68]P.S. Thenkabails, C.M. Biradar, H. Turral, P. Noojipady, Y.J. Li, J. Vithanage, V. Dheeravath, M. Velpuri, M. Schull, X.L. Cai, R. Dutta, "An Irrigated Area Map of the World (1999) Derived from Remote Sensing," Research Report 105, International Water Management Institute, 65p, 2006.

[69]A. Vibhute, S.K. Bodhe, "Applications of image processing in agriculture: A survey," International Journal of Computer Application, 52 (2), pp. 34-40, 2012. 